\title{
Institutional Environments And The Internationalization Of Franchise Chains: The Contrasting Cases Of Three North African Countries
}

\author{
E. Hachemi Aliouche, Rosenberg International Franchise Center \& University of New Hampshire, USA \\ Dominique Bonet Fernandez, IPAG Business School \& Aix-Marseille Université, France \\ Odile Chanut, Aix-Marseille Université, France \\ Nadjoua Gharbi, Université de Constantine, Algeria
}

\begin{abstract}
Franchising has become a dominant model of retailing in the Western world and is rapidly expanding in emerging countries. This paper is an attempt to explain the significant differences in the development of franchising in three emerging countries: Morocco, Algeria and Tunisia. Explanations can be found in the general institutional environment in these countries, including the political and economic environments; governments' willingness to modernize the distribution structures; and the legal and regulatory environments specific to franchising.
\end{abstract}

Our analytical framework is based on institutional theory (DiMaggio \& Powell, 1983), a framework that provides further insights beyond the approaches based on economic efficiency (agency theory and the resource scarcity perspective). Based on an analysis of the documents in the major public databases in the three countries, supplemented with field research, we propose an analytical framework that helps explain the uneven developments of franchising in the three North African countries based on the specific institutional environment of each country. This study thus provides empirical evidence supporting the institutional theory of franchise expansion. It appears that institutional theory complements agency theory and resource scarcity theory in explaining the development of franchising in emerging markets: while agency theory and resource scarcity theory explain the motivation of firms to expand internationally through franchising, institutional theory helps explain the success or failure of these firms in the emerging markets they expand to.

Keywords: Institutional Environment; Institutional Theory; Analytical Framework; International Expansion; Franchise Chains Maghreb

\section{INTRODUCTION}

61 f all 3 nations of Maghreb area, Morocco is considered the fastest growing country in terms of franchise networks. The franchise industry shows remarkable growth (24\% annual average over the period 1997-

2006) and today more than 400 networks are established with nearly 3,200 sales outlets in major cities of the kingdom ${ }^{1}$. The first international fair, Morocco Trade Expo was held in Casablanca in April 2013. Today, brands such as H \& M, Galeries Lafayette, Starbucks, American Eagle Outfitters, Llaollao, Payless, FNAC, New Look, Burger King or GAP leave no doubt about the development plans throughout the country ${ }^{2}$.

\footnotetext{
${ }^{1} \mathrm{http}: / / \mathrm{www}$. franchiseparis.com/?IdNode=6281\&Lang=FR

${ }^{2}$ http://www.aujourdhui.ma/maroc-actualite/economie/franchises-du-morocco-mall-des-plans-ambitieux-de-developpement-au-maroc-81284.html 
In Algeria, tens of international brands such as Lacoste, Timberland, Swatch or Benetton are present ${ }^{3}$. Simultaneously and strikingly, other brand names were withdrawing from the Algerian market. In February 2009, Carrefour closed down the hypermarket operated by Label'Vie, just two years after signing the franchise contract, even though the agreement planned the opening of 18 hypermarkets by 2012. The Etam, Naf Naf and Celio brands also put an end to their franchise experiments in Algeria (LSA No. 2079). Quick, the largest European fast food franchisor, closed its three outlets and left Algeria in November 2011 after four years in the country (Algerie-dz, January 31, 2012). Such a situation begs the question of what are the causes of such uneven development of franchising in countries that are so close geographically, culturally, linguistically and economically.

In developed countries, franchising has emerged as a dominant model in the distribution of products and services (Boulay \& Chanut, 2010). Franchising associates by contract a franchisor (the owner of a brand name, a distinctive concept, solid know-how, and tacit business practices) who wants a rapid duplication of outlets, and a franchisee, an independent entrepreneur, who joins a franchise chain in order to have access to a successful business system. The success of franchising is a reality in Western economies. For example, franchised chains represented in 2007 between 450,000 and 910,000 establishments in the USA, depending on sources, or between 7.9 and 11 million jobs in the U.S. economy (Kosová \& Lafontaine, 2011). France has 1,569 franchise chains and 62,041 franchised outlets (Fédération Française de la Franchise, 2012). So what about the development of franchise chains in North Africa, and more specifically, Morocco, Algeria and Tunisia? To what extent does the institutional environment in these three countries have a bearing upon this development? Our purpose is to address these questions, and show that institutional theory helps explain the evolution of franchising in these emerging countries.

Our focus on Morocco, Algeria and Tunisia is motivated by at least two important factors. First, it is striking how different the development of franchising has been in these three countries that are so similar in many keys aspects (apart from the oil-oriented production in Algeria). These three North African countries, collectively called the Maghreb, share a common geographic location and a common history that goes back centuries. They also share a common religion, a common language and a common ethnic make-up. Yet, the development of franchising in these three countries could hardly be more different. While in Morocco franchises are quickly expanding, particularly spurred on by French (38 percent of franchise systems) and American (12 percent of franchise systems) franchisors, it is failing to take hold in Algeria. Tunisia, on the other hand, has experienced an intermediate situation due to a law passed in August 2009 that set the legal framework for franchising. Thus it appears that these three fundamentally similar countries would provide an almost ideal case of investigating the impact of institutional factors on the development of franchising.

Second, the Maghreb countries are an important emerging market for international investors (over 81 million potential consumers; close to $\$ 550$ billion in total gross domestic product; fast growth in both population and GDP; strategic location with proximity to Europe, Africa, and the Middle East). Beyond European investors, because of historical links and beyond American investors, because of the free trade agreement signed in 2004 between the U.S. and Morocco, the area attracts investors from other continents. The market penetration of rising countries such as Brazil, Russia, India and China has increased since the mid-2000s, due to its strategic centrality and to the considerable business opportunities it offers (Moisseron et al., 2013). For example, China is already the second exporter to North Africa in 2011. Brazil is no exception, multiplying by four its food exports to North Africa between 2005 and 2011, reaching 2.5 billion USD in 2011 (Moisseron et al., 2013). International franchisors could invest in the Maghreb. Yet Maghreb countries have been neglected in franchising research.

While several papers on franchising in emerging countries can be found in academic reviews (Welsh et al., 2006, for example, counted more than 30 articles between 1988 and 2005), we did not find any paper comparing the expansion of franchises in the North African (Maghreb) countries. The size and proximity of the Maghreb should be of great interest to European franchisors looking for international growth, and particularly for French franchisors. The international growth of French franchisors in the three North African countries (that were French colonies or

${ }^{3}$ www.liberte-algerie.com/management/lafranchise-un-moyen-de-developper-l'entrepreneuriat_chez_les_jeunes.html 
protectorate for over a century) seems natural enough due to their geographic, historical, cultural and linguistic proximity. Links with the European Union are particularly important since the Euromed initiative ${ }^{4}$.

Our research approach is based on the hypothesis that the development of foreign, then local franchising in an emerging market depends on the institutional environment of the host country. This study proceeds as follows. First, we briefly discuss franchising in emerging markets. Then we present the importance of the institutional environment (public policies, legal rules, customs duties, business infrastructure...) in the development of franchising in emerging markets. We then analyse the major differences in the development of franchising in the three countries of the Maghreb and we relate them to the respective governments' differing policies to modernise trade and create institutional environments friendly to foreign investment in general, and franchise companies in particular.

Our analysis is based on the official figures published by state agencies when they exist, other secondary sources, and a field study. This study consists of an inventory of franchise chains in the Maghreb and interviews with Maghreb experts and heads of the French brand name networks established there ${ }^{5}$. Our data is documented through the official figures provided by state agencies and franchise associations and other secondary sources: legal framework, Tunisian law of August 2009 and other data (economic, demographic) from the World Bank and AT Kearney.

The interview guide used included four themes: experiences, challenges, choice of target countries and cities. The interviews were fully recorded, transcribed and then analyzed through thematic content analysis. Finally, an interview was conducted with an expert in Maghreb geopolitics.

This study provides evidence supporting the key role played by the institutional environment for the successful development of franchising in emerging markets.

\section{FRANCHISING IN EMERGING MARKETS}

Academic research shows that emerging markets are a favoured target for international distribution networks, particularly because they concentrate 80 percent of the world population, 60 percent of the natural resources, and represent the largest long-term potential for business growth (Welsh et al., 2006). Distribution networks have developed in Central and Eastern Europe, in Mexico and South America, in Asia (Isa et al., 2012), and in some African countries, including South Africa, Egypt, and since the 1990s, the Maghreb.

Emerging markets share a few characteristics that explain their attractiveness for distribution concepts: apart from their young populations, they generally experience high growth rates; have an already significant urbanization rate; a middle class eager to adopt Western lifestyles and consumption habits; increasing vehicle ownership; and improving infrastructure quality; all important elements for the rapid development of distribution concepts (Abbad et al., 2012; Isa et al., 2012).

There are different processes of international development: direct investment by creating directly owned and managed affiliates; joint-ventures materializing a partnership agreement with a local firm to develop the network together in the host country; area agreement with a local firm empowered with the right to develop the network in the host country; master-franchise - an area agreement in which the local firm plays the role of franchisor; or direct franchise with the recruitment and management of local franchisees from the country of origin (Duniach-Smith K., 2003 ; Boulay \& Chanut, 2010). While the selected methods do not seem to be the ultimate determinant of the success of the venture, market entry modes that rely on local firms (area agreement, masterfranchise, direct franchise) have significant advantages for franchisors, as they are able to rely on motivated local partners, franchisees or master-franchisees, and managers, who would directly benefit from the success of the

\footnotetext{
${ }^{4}$ Since 2008, with the 28 European Union member states, 16 Southern Mediterranean, African and Middle Eastern countries are members: Albania, Algeria, Bosnia and Herzegovina, Croatia, Egypt, Israel, Jordan, Lebanon, Mauritania, Monaco, Montenegro, Morocco, the Palestinian Authority, Syria, Tunisia and Turkey. Source: .http://www.eeas.europa.eu/euromed/index en.htm

${ }^{5}$ Interviews conducted in "Franchise Expo Paris" on 22-23 March 2010 with leaders of major franchise networks: Speedy, Carré Blanc, Geneviève Lethu, Réponse Lit (8 interviews).
} 
venture (since they keep the residual profit after paying the up-front fee and on-going royalties to the foreign franchisor). According to agency theory, these arrangements are a source of effort and motivation (Jensen \& Meckling, 1976; Fladmoe-Lindquist \& Jacque, 1995; Stanworth et al., 2001). The partners are also present locally in the target territory and they are thus embedded into the local social and business networks and enjoy an in-depth knowledge of the local market, of the values and habits of the local market participants, and of the economic and political structures of their country and region. Their social positions are sources of legitimacy and contribute to the acceptance of a distinctive foreign concept. Their relationship and close identity with local consumers contributes to the concept's notion of proximity (Capo \& Chanut, 2012) and to a successful installation of the first stores, due to a possible adaptation of the original concept to local demand. Their knowledge of the institutional environment is particularly valued in countries where legal, bureaucratic, and customs constraints are uneasy to master by foreign players. While the literature has for a long time shown that networks rely on franchising for outlets geographically distant from head offices (Brickley \& Dark, 1987; Norton, 1988; Lafontaine, 1995; Bercovitz, 2001), the role of the institutional environment of the host countries in the success or failure of franchise ventures in emerging markets, and therefore of the development of franchising in these markets, has been studied much less extensively. A major objective of this study is to highlight the key role of institutional factors in the development of franchising in emerging markets.

The choice of host countries, for franchisors wishing to go international is based on several criteria. In addition to geographical and cultural distances (Aliouche \& Schlentrich, 2011), economic criteria (development level, potential for growth) (Alon \& Mckee, 1999), market governance rules and the institutional environment (Welsh et al., 2006) are also taken into account, particularly to assess the level of risk associated with investment in host countries. Installation in a host country implies that this country offers an institutional environment compatible with the franchisors' interests.

\section{THE IMPORTANCE OF THE INSTITUTIONAL ENVIRONMENT}

The significant international development of franchise chains is not a phenomenon restricted to the Western world: the last ten years have seen a strong move toward the internationalization of franchising, spurred on by franchisors seeking new markets when faced with saturation in their home markets. While many franchise chains have not had a real strategic approach in terms of international expansion (Aliouche et al., 2012), two groups of factors play key roles in the choice of franchising as vehicle for international development (Eroglu, 1992) : organizational factors characterizing the franchise system (size, experience in the management of franchised outlets, level of risk tolerance, awareness of possessing a competitive advantage, international orientation of the managing team) and environmental factors external to the firm. Among the factors in the second group are the elements associated with the environment of the network's domestic market (competitors' presence, market saturation, roles of banks, governments, chambers of commerce and other institutional players), and the factors associated with the host market, particularly the political, economic, legal, and regulatory environments of the host country.

The issue of the influence of the institutional environment on the international strategies of companies is not new (Lawrence \& Lorsch, 1969; Davis \& North, 1970; North, 1990; Di Maggio \& Powell, 1991; Powell, 1996; Oliver, 1997; Peng 2000, 2002). The institutional framework is defined by Davis \& North (1971) as the set of fundamental political, social and legal ground rules that establish the basis for production, exchange and distribution. According to North (1990), institutions are the rules of the game in a society or, more formally, are the human-devised constraints that shape human interaction. For Powell (1996), researchers should investigate the forms, motivations and circumstances of the inclusion of the institutional environment in firms' strategies. In this perspective, Combs et al., (2009) show how both environmental and internal institutional pressures influence a firm's propensity to franchise, but that responsiveness to internal institutional pressures declines as economic reasons to franchise increase. Overall, social factors appear to actively influence franchising, but their impact is muted by economic factors. Aligned with these findings, Gauzente \& Dumoulin (2012) suggest that the persistence of franchising in the organization of retail networks can be explained by institutional theory and argue that institutional forces exert their influence at multiple levels. From this point of view, Peng (2002) formulated the question of the influence of institutions in the implementation of differentiated strategies from one country to another by a given firm, and demonstrated that strategic choices were the result of both formal and informal institutional constraints, conditions in the industrial environment, and the firm's specific resources. 
While research on franchising was until recently generally fuelled by considerations of economic efficiency through the agency theory or the resource scarcity perspective, other approaches seem to offer alternative explanations and have begun to be used (Barthelemy, 2011). This is the case of sociological explanations that assert that the choice of an organizational form depends on standards, values and rules coming from the institutional environment and on a desire to comply with a dominant model (DiMaggio \& Powell, 1983). The players' rationality is then replaced by a mimetic rationality: for example, a shared belief that franchising is an optimal organizational form for ensuring the development of the economic activity or the shared belief that the host country's institutional environment is favourable to franchising.

The institutional environment is a key factor for understanding whether a franchise chain is expanding in a host country or exiting this country. It conditions the legitimacy of a franchise with partners supplying resources for the development of franchised outlets, with banks and prospective franchisees particularly (Dumoulin \& Gauzente, 2009; Barthelemy, 2011). Yang et al. (2012) showed that firms adapt their strategies to the varied institutional environments of host countries in order to gain legitimacy and efficiency by customizing contracts and following relationship governance.

Thus, it appears that while agency theory and resource scarcity theory are instrumental for explaining the motivation of firms to adopt the franchise business model, institutional theory is well suited for explaining the choice of host markets and the likely success or failure of the development of franchising in emerging markets. Based on institutional theory, we hypothesize that franchising will develop more successfully in emerging countries with more favourable institutional environments. We illustrate this hypothesis by analysing the evolution of franchising in three emerging countries that have essentially similar fundamental attributes (physical location, history, culture, language, religion, etc.), but have very distinct institutional environments: Morocco, Algeria, and Tunisia, the three North African countries collectively known as the Maghreb.

To explain the differences in the development of franchising in these three countries, we propose an analytical framework of the institutional environment suitable for distribution networks in general and for franchisors' interests in particular. This framework is organized around three groups of criteria related to the institutional environment: those associated with the country risk and the social climate of the host country (political and economic environments); those relating to the existence of modern business structures (business infrastructure); and those centred on laws and institutions favourable to franchising.

The first group of criteria captures the host country's political and economic environments. Adverse economic and political conditions or changes in a host country (currency instability, increased tariffs, bank stability, unemployment rate, government finances, monetary policy, debt defaulting, corruption, government stability, strikes, boycotts, etc.) may result in losses for the franchise companies operating there (Aliouche \& Schlentrich 2011, Cosset \& Doutriaux de la Riancerie 1985, Clark \& Tunaru 2003, Erevelles et al. 2005, Rothaermet et al. 2006, Hoffer \& Haller 1980, Welsh et al. 2006). These political and economic risks are regularly assessed by a number of institutions. For example, Euromoney has developed a Country Risk Index (Appendix A) that is widely used to capture a country's political and economic risks (Cosset \& Roy, 1991; Aliouche \& Schlentrich, 2011). We use it as a proxy for political and economic environment.

The second group of criteria relates to the development of performing business infrastructures that would support market activities (Business Infrastructure). This group focuses on conditions needed to develop modern distribution structures in an emerging country, as large and medium food stores besides traditional trade structures or as small outlets networks. This development is operated by foreign retailers investing under specific conditions: suppression of tariff/quota barriers, free flow of capital, improvements in supply chain organization, logistics, and management, quality of transportation infrastructures and storage facilities, (Weatherspoon et al., 2004). In terms of legal and regulatory environment, the World Bank's Doing Business Index has been extensively used in the academic literature (Aliouche \& Schlentrich, 2011) (Appendix B). Focused on the retail industry, the Global Retail Development Index is also used to analyze retail-specific variables to help retailers devise successful global strategies and to identify developing market investment opportunities. In addition to these two indexes, we use specific variables for franchise Business Infrastructure. A key factor for franchisors is the possibility to import goods into the host country coupled with the possibility to cash in and repatriate up-front fees and royalties. In a 
franchise agreement, the franchisor can be considered a service provider bringing marketing resources (brand name, communication on the brand name, and a proven distinctive business concept) as well as know-how and on-going assistance to the franchisee. Franchisors generally receive compensation for this service in the form of up-front fees for joining the network and royalties on the turnover of the franchisee store network (master franchise). It is important for franchisors to actually cash in this compensation, which is the case only in countries authorizing capital outflow. Although with product franchising, it is always possible to get around regulations preventing the repatriation of funds by fixing higher purchase prices for imported goods, the ban on funds transfers to foreign countries is a barrier for service franchising and may explain the low rate of development of franchise chains in many countries.

Our institutional environment framework includes a logistics performance index developed by the World Bank including the time required for customs clearance and the use of new information technologies and modern management tools. We also include in this group the existence, in host countries, of training for marketing and managerial positions which makes it easier to recruit marketing supervisors and the development and monitoring of statistics on trade structures by the public authorities, and laws on commercial leases (Welsh et al., 2006). The development of modern business structures implies a right to lease that protects the owners of commercial premises and ensures them enough operation time in their premises.

The third group of proposed criteria is centred on laws and institutions dedicated to franchising (Franchise Laws and Franchise Institutions). Three main sources for franchise dissemination as an organizational standard in a country were identified from DiMaggio and Powell (1983) typology on institutional isomorphism. The first is the coercive source referring to laws and regulations. Many governments are in the process of improving their country's business environment to attract high quality franchises. Improvements have included favourable legislation for franchise regulations (Welsh et al., 2006). The first step here is the recognition of franchising as a possible organizational form for business activities, and government recognition that franchising has a key role in the modernization of local business practices. In those economies most open to franchising, franchise laws are developed to protect partners and ensure balanced relationships between franchisors and franchisees (Shane \& Foo, 1999; Combs et al., 2004). New franchising legislation may imitate what exists in countries where franchising has reached maturity: obligation of pre-contractual information to protect the consent of franchisees, protection of the know-how of franchisors, adaptation of intellectual property rights and other measures to efficiently fight counterfeiting damaging to brands. Cooperation mechanisms have been implemented by the European Union to allow institutional and regulatory convergence, such as twinning, cooperation instruments provided by European Community institutional and regulatory framework, (Moisseron et al., 2013).

The second source of franchise dissemination, called normative, comes from the professional sector and includes training efforts and definition of working methods by the players in a given industry. In this context, the work of consultants and professional franchise organizations, such as federations of franchise, is important (Shane \& Foo, 1999; Combs et al., 2004; Dumoulin \& Gauzente, 2009; Boulay \& Chanut, 2010; Antonowicz, 2011). The International Franchising Association is a major clearinghouse for practitioner-focused franchising information (Combs et al., 2004). Local franchise associations can also be created. Their panels of experts and lawyers often implement ethical codes protecting the interests of the franchise partners, helping to secure this organizational form. They also promote this mode of organization with all relevant parties, including the public authorities that legislate and enforce the franchise laws and regulations. They can organize conferences, forums and other franchise events to gather both national and foreign franchisors and prospective franchisees. Finally, they can organize training sessions for trade and franchise jobs (Boulay \& Chanut, 2010). The banks may play a normative role too when they develop departments dedicated to franchise that decide whether to facilitate access to credit for the member firms of a franchise chain (Stanworth \& Curron, 1999; Dumoulin \& Gauzente, 2009; Barthelemy, 2011).

The third source of franchise dissemination is derived from cognitive and mimetic behaviour (DiMaggio \& Powell, 1983). Players include a cognitive framework inspired by the experiences of others. They adopt the franchise model when they see that this is a successful model and then internalize the ideas conveyed in the franchise (fastest way to develop a concept, minimizing financial risks and controlling the distribution) (Boulay \& Chanut, 2010). Thus one can make the assumption that local actors launch franchise networks when foreign franchisors have successfully broadcast the model in a country. 
The framework depicting the institutional environment of franchising in Table 1 helps explain the differences in franchising development in the three countries of the Maghreb.

Table 1: Analytical Framework Of The Institutional Environment Of Franchising

\begin{tabular}{|c|c|}
\hline Groups Of Criteria & Detailed Criteria \\
\hline $\begin{array}{c}\text { Political and Economic } \\
\text { Environment }\end{array}$ & $\begin{array}{ll}- & \text { Government stability } \\
- & \text { Corruption } \\
- & \text { Strikes and boycotts } \\
- & \text { Currency stability } \\
- & \text { Increased tariffs } \\
- & \text { Bank stability } \\
- & \text { Debt }\end{array}$ \\
\hline Business Infrastructure & $\begin{array}{ll}\text { - } & \text { Freedom of circulation of goods and funds } \\
\text { - } & \text { Possibility of cashing-in and repatriating payments in the franchisor's country (up-front fee } \\
\text { - } & \text { Existence and development of food super and hypermarkets } \\
\text { - } & \text { Quality of transport and storage infrastructures } \\
- & \text { Index of logistics performance } \\
- & \text { Training to marketing and management positions } \\
- & \text { Development and monitoring of statistics on trade structures } \\
- & \text { Right to a safe lease for commercial premises }\end{array}$ \\
\hline $\begin{array}{l}\text { Franchise Laws and } \\
\text { Franchise Institutions }\end{array}$ & $\begin{array}{ll}- & \text { Legal recognition of franchise } \\
- & \text { Construction of specific franchise laws } \\
- & \text { Respect for industrial property rights } \\
- & \text { Development of statistics on franchising } \\
- & \text { Creation of franchise associations or federations } \\
- & \text { Organization of franchise trade fairs } \\
- & \text { Specific offers from banks to finance franchise } \\
- & \text { Existence of professional training for franchises }\end{array}$ \\
\hline
\end{tabular}

\section{DEVELOPMENT OF FRANCHISING IN THE MAGHREB}

The purpose of this chapter is to explain the differences in the development of franchising in the three countries of the Maghreb and relate them to the institutional environments of franchising in these countries. While franchising is fast growing in Morocco, it has not taken off in Algeria. Tunisia is between the two (see Table 2).

\section{A. Morocco}

It is easy to assess the situation of franchise chains in Morocco, due to the regular issuing of statistics on franchising by the Moroccan Ministry of Commerce ${ }^{6}$. There are about 440 franchise chains in Morocco and about 3,200 franchised outlets, in various sectors of activity. Most networks are of foreign origin. 38 percent of them are French brands (see examples in Table 3), and this helps to confirm the idea developed in the literature that demonstrates that networks establish themselves in the nearest countries in terms of geography, language and culture (Aliouche \& Schlentrich, 2011). The historical links between France and the North African countries explain these commercial links. But Moroccan franchise chains exist alongside foreign networks and already represent 15 percent of the Moroccan networks (or 52 networks). Some, such as Marwa or Kiotori are even beginning to export their concepts to France and Europe. In addition, while 46 percent of franchised outlets are located in the three largest cities (Casablanca, Rabat and Marrakech), more than half are located in smaller towns, which means a significant spread of franchisees in Morocco. We can say that franchising in Morocco is now a meaningful marketing system in the growing phase of its life cycle.

${ }^{6}$ Franchise statistics in Morocco in July 2010, Sources: Ministry of Industry, Commerce and Telecommunications of Morocco. http://www.mcinet.gov.ma/mciweb/mciweb/mci_mod_rub_w_1.jsp?codem=58\&coded=3\&codet=Commerce 


\section{B. Algeria}

In this country, there are no official statistics and this makes it difficult to carry out a detailed count. However, it is estimated that there are less than 70 franchise chains (Gharbi, 2012). The foreign brands established in Algeria hold 1 to 3 outlets, exclusively located in Algiers, in fashionable districts and targeting foreign customers and tourists, even hotels. In addition, several networks have recently announced the closing down of their franchisee stores in Algeria. We can say that franchising as a marketing system has not been able to take off in this country.

\section{Tunisia}

Tunisia offers an intermediate situation. The country has recognized franchises only very recently (2009). As a consequence, partnerships between foreign networks and Tunisian firms to operate stores according to imported concepts were qualified as brand licenses, know-how or technical assistance agreements, or other formulations. But they existed and looked quite like franchises. The first store under this organizational form may go back to 1933 (agreement with Monoprix, that nowadays has 71 stores in Tunisia, LSA No. 2100). Other French franchise brands are present ${ }^{7}$ in Tunisia, and they started developing significantly in the 1990s. This is the case of mass food distribution which modernized in Tunisia, with Carrefour, present since 2001 (45 outlets under the Champion, Carrefour Market, and Carrefour Express brand names), and also Géant Casino (since 2005, 1 hypermarket). Système U announced the opening of a hypermarket in 2012, just before the Jasmine revolution. Two Tunisian brands are thought to be operated as franchises, also in the food retailing sector: Elmazraa (532 stores, with 350 operated as franchises) and Chahia (95 units with 63 franchised) (Mseddi \& Bouri, 2010). Several other sectors look promising for franchising: real estate and luxury products. But as in Algeria, the lack of official statistics hampers the analysis of the actual development of franchising in Tunisia. The general director of competition and economic investigations in the Ministry of Commerce described Tunisia's experience with franchising as "modest and budding ", which, according to him, does not prevent the existence of "a few successful franchise experiments under a few national or foreign brand names" (quoted by Mseddi \& Bouri, 2010).

${ }^{7}$ Even if the agreements have other legal qualifications. 
Table 2: Comparison Of Franchising Development In The North African Countries

\begin{tabular}{|c|c|c|c|}
\hline & Morocco & Algeria & Tunisia \\
\hline Date of 1st franchise & 1962 & 2003 & 1933 (Monoprix) \\
\hline Number of franchise chains & 440 & Less than 40 & About 150 \\
\hline Number of franchisee stores & 3,200 & Not available & Not available \\
\hline Geographical location & $\begin{array}{l}46 \% \text { in the } 3 \text { largest cities } \\
\text { (Casablanca } 27 \% \text {, Rabat } 11 \% \text {, } \\
\text { Marrakesh } 8 \% \text { ) } \\
\text { Franchises spreading to smaller } \\
\text { towns }\end{array}$ & $\begin{array}{l}\text { Limited to Algiers, } \\
\text { concentrated in fashionable } \\
\text { districts (e.g.: Sidi Yahia) }\end{array}$ & Concentrated in large cities \\
\hline Weight of national franchise & $15 \%$ of Moroccan networks & Not available & Not available \\
\hline Foreign countries & $\begin{array}{l}38 \% \text { France, } 12 \% \text { USA, } 11 \% \\
\text { Italy, } 7 \% \text { Spain }\end{array}$ & Not available & Not available \\
\hline $\begin{array}{l}\text { Examples of foreign franchise } \\
\text { (number of stores) }\end{array}$ & $\begin{array}{l}\text { Label'Vie (Carrefour, } 12 \\
\text { hypermarkets following } \\
\text { purchase of the } 10 \text { Metro cash } \\
\text { and carry), } \\
\text { Quick (9) }\end{array}$ & $\begin{array}{l}\text { Yves Rocher, Mango, Quick, } \\
\text { Jacques Dessange, Frank } \\
\text { Provost, Levi’s, Carré Blanc, } \\
\text { Benetton, Lacoste, Le Tanneur, } \\
\text { Sergent Major, Ooxoo, } \\
\text { Timberland, Nike, Jules... } \\
\text { Withdrawn: Carrefour, Naf } \\
\text { Naf, Célio }\end{array}$ & $\begin{array}{l}\text { Monoprix (71), Carrefour (45), } \\
\text { Géant Casino (1), Système U (1 } \\
\text { project 2012), Hertz, Avis, } \\
\text { groupe Zannier (Absorba, } \\
\text { Catimini, Chipie, Ikks, Kenzo } \\
\text { Kids etc.) }\end{array}$ \\
\hline $\begin{array}{l}\text { Examples of national } \\
\text { franchise }\end{array}$ & $\begin{array}{l}\text { Marjane (20 hypermarkets), } \\
\text { Acima (30 supermarkets) } \\
\text { Marwa, Venezia Ice, Hanouty, } \\
\text { Kiotori, Mobilia, Yatout }\end{array}$ & $\begin{array}{l}\text { Djazair Trade-Retail } \\
\text { Nesk Algeria }\end{array}$ & $\begin{array}{l}\text { Magasin général (45) } \\
\text { Cerina Beauté (20), Zen (13), } \\
\text { Chahia ( } 95 \text { with } 63 \text { in } \\
\text { franchise), Elmazza ( } 532 \text { with } \\
350 \text { in franchise) }\end{array}$ \\
\hline $\begin{array}{l}\text { Activity sectors of franchisee } \\
\text { networks }\end{array}$ & $\begin{array}{l}\text { Clothing trade } 26 \% \text {, Furniture } \\
7 \% \text {, Restaurants } 6 \% \text {, Shoe } \\
\text { trade } 5 \% \\
\text { others } 56 \%\end{array}$ & Not available & $\begin{array}{l}\text { Service franchising slow to } \\
\text { develop (difficult to repatriate } \\
\text { up-front fees and royalties) }\end{array}$ \\
\hline
\end{tabular}

Sources: Moroccan Ministry of Commerce July 2010 data, Annex 1), Mseddi and Bouri, 2010, Gharbi 2008, LSA n 1841, 2078, 2151, 2161

\section{IMPACT OF THE INSTITUTIONAL ENVIRONMENT ON FRANCHISING IN THE MAGHREB}

As presented earlier, our central hypothesis is that the development of franchising in an emerging country is determined by its institutional environment. We will now explain the differences in the development of franchising in the three countries of the Maghreb on the basis of their respective institutional environments. As described earlier, the three North African countries of Algeria, Morocco, and Tunisia are similar in key aspects. They share a common history; a common religion; a common language; a common ethnic make-up; and a common geographic location. Morocco and Algeria have populations of comparable sizes. The growth rates of the three economies are comparable. The per capita incomes of Algeria and Tunisia are comparable; while that of Morocco is much lower (Table 3). Yet, franchising is much more developed in Morocco than in either Algeria or Tunisia.

Table 3: Demographic Comparison And Development Level Of The Maghreb Countries (2010)

\begin{tabular}{|c|c|c|c|}
\hline & Morocco & Algeria & Tunisia \\
\hline Number of inhabitants & 32 millions & 35 millions & 10.5 millions \\
\hline Urbanization rate & $58 \%$ & $66 \%$ & $66 \%$ \\
\hline Growth rate & $3.2 \%$ & $3.3 \%$ & $3.7 \%$ \\
\hline $\begin{array}{l}\text { Gross per capita income (in } \\
\text { USD) }\end{array}$ & $4,627.6$ & $8,320.2$ & $7,979.3$ \\
\hline $\begin{array}{l}\text { Human development index } \\
\text { (HDI) }\end{array}$ & $\begin{array}{l}0.567 \\
\text { Average human development } \\
\text { group }\end{array}$ & $\begin{array}{l}0.677 \\
\text { High human development } \\
\text { group }\end{array}$ & $\begin{array}{l}0.683 \\
\text { High human development } \\
\text { group }\end{array}$ \\
\hline Others & $\begin{array}{l}7.5 \text { million tourists / year } \\
53 \text { vehicles } / 1000 \text { inhabitants }\end{array}$ & Not known & $\begin{array}{l}6 \text { million tourists / year } \\
71 \text { vehicles/1000 inhabitants. }\end{array}$ \\
\hline
\end{tabular}

Source : hdrstats.undp.org/fr/pays/profils/TUN.html (HDI figures for $2010^{8}$ )

${ }^{8}$ In comparison, the OECD countries have an average HDI of 0.879; France has a HDI of 0.872 .

http://hdrstats.undp.org/fr/indicateurs/90406.html (income per inhabitant, figures for 2010. France has an income per inhabitant of 34340,7 ).

http://www.statistiques-mondiales.com

Copyright by author(s); CC-BY 
Using the analytical framework of the institutional environment of franchising presented in Table 1, we describe the institutional environment of franchising in the three countries (Table 4) in order to confirm that this is where the causes of disparity in franchising development lie.

Table 4: Comparison Of Institutional Environments For Franchises In The North African Countries

\begin{tabular}{|c|c|c|c|}
\hline & Morocco & Algeria & Tunisia \\
\hline $\begin{array}{l}\text { Political and Economic } \\
\text { Environment } \\
\text { Euromoney, Country Risk } \\
\text { Index, 2010 (1) }\end{array}$ & 57 & 92 & 71 \\
\hline $\begin{array}{l}\text { Business Infrastructure } \\
\text { World Bank, Doing Business, } \\
2010(2)\end{array}$ & 114 & 136 & 55 \\
\hline $\begin{array}{l}\text { Global Retail Development } \\
\text { Index } 2010(3)\end{array}$ & 15 th & 21th (a loss of 10 places) & 11 th \\
\hline $\begin{array}{l}\text { Freedom of circulation of funds } \\
\text { Possibility to transfer up-front } \\
\text { fees and royalties abroad }\end{array}$ & Yes, transfers authorized & $\begin{array}{l}\text { Restrictive policy toward } \\
\text { foreign investments } \\
\text { - investment financing in dinars } \\
\text { only (not convertible) } \\
\text { - funds transfers strictly } \\
\text { controlled (royalty payments } \\
\text { prohibited) }\end{array}$ & $\begin{array}{l}\text { Royalty transfers prohibited up } \\
\text { to } 2009 \text { - hindrance for services } \\
\text { franchises particularly. } \\
\text { Since } 2009 \text {, royalty payment is } \\
\text { possible, but remains under the } \\
\text { control of the Banque Centrale } \\
\text { Tunisienne }\end{array}$ \\
\hline $\begin{array}{l}\text { Attitude of public authorities } \\
\text { concerning trade / franchise } \\
\text { modernization }\end{array}$ & $\begin{array}{l}\text { Rawaj } 2020 \text { development plan } \\
\text { with ambitious objectives : } \\
\text { - increase trade from } 11 \text { to } 17 \% \\
\text { of GDP } \\
\text { - build } 900 \text { large-scale stores } \\
\text { - create } 450,000 \text { jobs } \\
\text { The plan targets retail trade, } \\
\text { bulk trade, medium and large- } \\
\text { scale distribution }\end{array}$ & $\begin{array}{l}\text { Unfavourable up to now, but } \\
\text { recent awareness that franchises } \\
\text { are interesting for the Algerian } \\
\text { economy. Constitution of a } \\
\text { commission to prepare } \\
\text { regulations on franchises, and } \\
\text { suggest methods for codifying, } \\
\text { organizing and controlling } \\
\text { franchise activities. }\end{array}$ & $\begin{array}{l}\text { At the beginning of } 2009, \text { the } \\
\text { government launched a trade } \\
\text { modernization policy, relying } \\
\text { on foreign distributors under } 2 \\
\text { conditions: creation of jobs and } \\
\text { quotas of local products } \\
\text { Before } 2009,2 \text { negative } \\
\text { experiments for foreign } \\
\text { distributors (McDonald's and } \\
\text { Pizza Hut) }\end{array}$ \\
\hline $\begin{array}{l}\text { Market share of large-scale } \\
\text { retailing }\end{array}$ & $10.0 \%$ & $\begin{array}{l}\text { Very low : informal trade is } \\
\text { dominant }\end{array}$ & $18.0 \%$ \\
\hline Logistics performance index (4) & 2.38 in 2006 ; NC in 2009 & $\begin{array}{l}2.06 \text { in } 2006 \text { and } 2.36 \text { in } 2009 \\
\text { (progressing) } \\
\text { The lowest in the } 3 \text { countries }\end{array}$ & $\begin{array}{l}2.76 \text { in } 2006 \text { and } 2.84 \text { in } 2009 \\
\text { (progressing, the best in the } 3 \\
\text { countries) }\end{array}$ \\
\hline Commercial real estate & $\begin{array}{l}\text { No right of lease protecting } \\
\text { trade premises, hence } 18 \% \\
\text { unoccupied trade premises in } \\
\text { Casablanca }\end{array}$ & & \\
\hline
\end{tabular}

(1) www.euromoney.com/Article/2675660/Country-risk-Full-results.html

(2) www.doingbusiness.org/rankings

(3) www.atkearney.com/global-retail-development-index

(4) www. donnees.banquemondiale.org/indicateur/LP.LPI.OVRL.XQ r, the overall score of the logistics performance index reflects how logistics in a country are perceived based on the efficiency of the customs clearance processes, the quality of trade infrastructures and transport infrastructures. It ranges from $1=$ low to $5=$ high. 


\begin{tabular}{|c|c|c|c|}
\hline & Morocco & Algeria & Tunisia \\
\hline $\begin{array}{l}\text { Franchise laws and } \\
\text { institutions } \\
\text { Statistics on franchising }\end{array}$ & Yes, detailed and regular & No official data & No official data \\
\hline Laws on franchise & $\begin{array}{l}\text { No specific laws (trade laws, } \\
\text { labour laws, intellectual } \\
\text { property laws, competition } \\
\text { laws, currency exchange laws) } \\
\text { But no law opposed to } \\
\text { franchise }\end{array}$ & $\begin{array}{l}\text { No specific laws, but the law } \\
\text { does not encourage } \\
\text { franchising : } \\
\text { - consumer credit forbidden }\end{array}$ & $\begin{array}{l}\text { Before 2009: no recognition of } \\
\text { franchises. Players bypassed } \\
\text { the difficulty by fragmenting } \\
\text { the agreement (brand license, } \\
\text { partnership agreements, know- } \\
\text { how agreement, technical } \\
\text { assistance) } \\
\text { The law of August 12, 2009, } \\
\text { on distribution trade } \\
\text { recognises franchising in its } \\
\text { Section 5, but no regulations } \\
\text { protecting franchisees' } \\
\text { acceptation (DIP) or } \\
\text { franchisors' know-how. } \\
\text { Application decree pending. }\end{array}$ \\
\hline $\begin{array}{l}\text { Franchise associations / } \\
\text { federations }\end{array}$ & $\begin{array}{l}\text { Franchise association created } \\
\text { in } 1997 \text {, and transformed into } \\
\text { the Federation Marocaine de la } \\
\text { Franchise in } 2002 \text {. The FMF is } \\
\text { a member of the World } \\
\text { Franchise Council. } 10^{\text {th }} \text { edition } \\
\text { of the franchise show in } 2010 \text {. } \\
\text { Numerous conferences } \\
\text { organized. }\end{array}$ & $\begin{array}{l}\text { Franchise association created } \\
\text { in } 2006,2 \text { franchise forums } \\
\text { organized since }\end{array}$ & $\begin{array}{l}\text { 1st edition of the Tunis Med } \\
\text { Franchise show in December } \\
10-12,2009.40 \text { exhibitors. } \\
\text { Organized by the Tunis } \\
\text { Chamber of Commerce and } \\
\text { Industry (CCIT), in } \\
\text { collaboration with the } \\
\text { Association of the } \\
\text { Mediterranean Chambers of } \\
\text { Commerce and the Tunisian } \\
\text { Industry, Trade and } \\
\text { Craftsmanship Union. } \\
3 \text { franchise fairs in 2010, } 2011 \\
\text { and } 2013 \text {. } \\
\text { The Association Tunisienne de } \\
\text { la Franchise (ATF) was } \\
\text { created by CCIT in 2006, with } \\
26 \text { franchise sectors. }\end{array}$ \\
\hline $\begin{array}{l}\text { Behaviour of banks toward } \\
\text { franchising }\end{array}$ & $\begin{array}{l}\text { Attijariwafa Bank and BCP } \\
\text { (Banque Populaire) } \\
\text { implemented specific offers } \\
\text { for franchisees : } 7 \text {-year credit } \\
\text { to franchisees covering up to } \\
70 \% \text { of the investment } \\
\text { programme (including fees } \\
\text { and royalties) with an upper } \\
\text { limit of } 1 \text { million dirhams }\end{array}$ & Not available & Not available \\
\hline
\end{tabular}

Sources: LSA No. 1774, AC franchise 22/12/2009, Adimi K. (2010), Mseddi and Bouri, 2010.

In terms of political and economic environment, according to the Euromoney Country Risk index, Morocco ranked 57, Tunisia 71 and Algeria 92 in 2010 (Table 4). Morocco thus appears to have the lowest political and economic risks for businesses, while Algeria had the highest risks. In terms of legal and regulatory environment, the World Bank's Doing Business Index shows Tunisia ranked, in 2010, as $55^{\text {th }}$ as the easiest country in the world to do business in, while Morocco ranked 114 and Algeria 136 (Table 4). It is to be noted, however, that even though in general Tunisia is easier to do business with than Morocco, the laws and regulations that have the most impact on franchising are much more favorable in Morocco than in Tunisia, as is discussed below. In terms of trade infrastructure, Tunisia is ranked best in the Maghreb, followed by Morocco. However, as is discussed below, some specific governmental policies have had a very detrimental effect on the development of franchising in Tunisia. 


\section{A. Morocco: A Deliberate Policy Of Promoting Modern Trade}

The success of foreign franchising is the result of laws and logistics conditions that favour franchisors' investments. On a political perspective, the king of Morocco concentrates most powers, but political stability is accompanied by a gradual process of democratization since the late ' $80 \mathrm{~s}$. Morocco has a dynamic of institutional change based primarily on institutional convergence with Europe, allowing the status of advanced partner of Europe (Moisseron et al., 2013). 29 partnerships were set up within the fields of foreign trade, maritime security and safety, consumer protection, fight against money laundering, competition, and intellectual property laws (Moisseron et al., 2013). These changes explain Morocco's rank on the Political/Economic Risk scale (rank 57, the best of three countries). However, franchising does not benefit from a specific legal framework in Morocco: partnership agreements are ruled under common law (trade laws, competition laws, labour laws). But franchising is recognized de facto and no regulations prevent its development. Specifically, foreign franchisors can repatriate their up-front fees and royalties. Additionally, the Moroccan government has adopted an ambitious development plan, expressing its desire to modernize the business infrastructure. The government's objectives are to boost trade services from 11 percent to 17 percent of GDP, to increase the number of large and medium area stores to 900, and thus to create 450,000 jobs. The retailing sector market share represents 10 percent of trade and should double by 2020 . The logistics performance index is also improving. As for franchise institutions, there again appears a will to promote both foreign and national franchising. The Moroccan franchise association created in 1997 became the Federation Marocaine de la Franchise in 2002, the only franchise association in the Maghreb to be a member of the World Franchise Council. It is very active, in particular, it has proposed an ethical code for franchising that would be very useful in the absence of laws protecting franchisees. Finally, two Moroccan banks have implemented specific offers to allow prospective franchisees to finance their premises and their membership in a franchise network. They grant a 7 -year credit covering up to 70 percent of the investment cost (including fees and royalties) with an upper limit of 1 million dirhams ${ }^{9}$. All in all, the institutional environment for franchising is favourable in Morocco and explains its strong development. The lack of laws protecting commercial leases is the only drawback: retailers have no longterm leases for their premises and this weakens them. This is one of the reasons why 18 percent of commercial premises are unoccupied in a city like Casablanca. The institutional environment for franchising has developed gradually in Morocco, despite the lack of a specific legal system. Policies are clearly in favour of the development of foreign franchising. They have allowed a strong growth of first foreign, than Moroccan franchise chains.

\section{B. Algeria: Restrictive Policies For Foreign Investments}

It is evident that there is no specific institutional environment for franchising in Algeria: no official statistics on franchising, no legal recognition of this organizational form, only one franchise association created in 2006 (which has organized only two meetings since). Public authorities have proved hostile to foreign franchisors, with a restrictive policy toward foreign investments: financing investments are only allowed in dinars (not convertible); funds transfers are strictly controlled: it is forbidden to pay royalties and to repatriate them. This is why product concepts franchising is more common, like ready-to-wear, compared to service concepts (Benmiloud, 2013). Other rules such as the ban on consumer credit or commercial lease legislation, do not favour business. Furthermore, while several of our respondents ${ }^{10}$ described «a potential in Algeria, due to a high demand, greater than that in Morocco », they simultaneously underlined regulatory and customs difficulties hampering goods delivery: «the issue is how do our products reach our shops? Customs procedures are very difficult in Algeria; custom officers are particularly fussy and the circulation of goods circulation is complicated. Algeria is more difficult than Morocco, in spite of a higher potential $\gg$. Not surprisingly, the logistics performance index is the lowest of the three countries ${ }^{11}$ (Table 4). However, while the authorities have not been much in favour of franchising up to now, it seems that a recent awareness of the beneficial nature of franchising for the Algerian economy has justified the constitution of a commission to prepare laws on franchising. It would be in charge of making propositions to codify, organize, and control franchise trade activities.

\footnotetext{
${ }^{9}$ Or about 90.000 Euros.

${ }^{10}$ Interviews conducted during Franchise Expo Paris, on March 22-23, 2010, with the Speedy, Carré Blanc, Geneviève Lethu and Réponse Lit brand names managers.

${ }^{11}$ Sources: www. donnees.banquemondiale.org/indicateur/LP.LPI.OVRL.XQ $r$, the global score of the logistics performance index reflects views on the logistics in a given country based on the efficiency of customs clearance processes, the quality of commercial infrastructures and transport infrastructures. It ranges from $1=$ low, to $5=$ high.
} 


\section{Tunisia: A Cautious Opening To International Trade And Franchise}

Tunisia presents a development of franchising that is in discrepancy with a number of indicators such as its economic potential and level of legal and regulatory risks that are more favourable to foreign investors than those of its neighbours: the country has opened up to international trade as its joining the World Trade Organization (WTO) in 1994 shows. The more favourable legal and regulatory environment in most business sectors is reflected in Tunisia's ranking in the World Bank's Doing Business Index: in 2010, it raked as $55^{\text {th }}$ as the easiest country in the world to do business in; while Morocco ranked 114 and Algeria 136 (Table 4). In addition, Tunisia already has modern trade structures, far more advanced than those of its neighbours (18 percent of retailing in large and medium area stores, and this figure could double in 10 years), thanks to partnerships with foreign food retailing groups (Carrefour, Metro up to recently, among others). The logistics performance index is the best in the three countries of the Maghreb. But there are relatively few franchises in the country. It appears that the reason is that Tunisian authorities adopted specific policies that discouraged the development of franchising and made it impossible for a Tunisian franchisee to pay royalties to a foreign franchisor (Mseddi \& Bouri, 2010). McDonald's and Pizza Hut, for example, could not establish themselves in Tunisia in 1993-1995 as the Ministry of Commerce and Craftsmanship refused an authorization for McDonald's and quickly withdrew its authorization to Pizza Hut (Mseddi \& Bouri, 2010). These obstacles explain the low development of service franchising in particular, as it is not possible to disguise royalties with higher purchase prices in this case.

The future of franchising seemed promising in Tunisia with the change of climate and the change of attitude of the Tunisian authorities toward franchising at the beginning of 2009, translated into a Section 5 of the Law of August 12, 2009, on retailing. The government, wishing to promote a modernization policy of trade, is encouraging foreign distributors, under two conditions: that they create jobs and respect quotas of local products. In fact, Section 5 officially recognises franchise agreements and offers a definition of the agreement ${ }^{12}$ (close to the European definition), requires a written agreement stating the rights and obligations of franchisors and franchisees, mentions the principle of a prior obligation of information (but refers the definition of its contents to a decree of application). Section 5 also recognises explicitly the right to pay royalties, and to transfer them abroad, under the control of the central bank and after authorization by the Ministry of Commerce (Mseddi \& Bouri, 2010). The authorities' desire to promote franchising, including foreign franchises, also resulted in the organization on December 10-12, 2009 of the first Tunis MedFranchise show. Fourty exhibitors participated. Three other editions of the show followed in December 2010, 2011 and February 2013. The last edition slogan was "franchise, a bright future". In addition, the Tunisian franchise association (Association Tunisienne de la Franchise-ATF) was created at the initiative of the CCIT ${ }^{13}$ in October 2010, following the first edition of Tunis MedFranchise with 26 franchise sectors.

The institutional environment of franchising in Tunisia is changing fast and this could allow the country to make up its development gap compared to its neighbour, Morocco. Several French franchisors announced their intention to expand to Tunisia in 2010. However Tunisia has entered a period of political turbulence since the onset of its "Arab Spring" in 2011. This undoubtedly will have an important impact on its institutional environment (Moisseron et al., 2013). Tunisia is experiencing a deep institutional break with the new regime and part of Tunisian society questioning the foundations of the Republic of Tunisia, including, its model of secular welfare state, its republican nature, and its partnership with Europe, in favor of a referential matrix oriented towards the legacy of Arabo-Islamic civilization.

\section{DISCUSSION}

The above survey of the development of franchising in the three countries of the Maghreb helps to validate the hypothesis that franchising spreads in emerging countries through the global expansion of international franchisors, supported or hindered by more or less favourable institutional environments in the host countries.

\footnotetext{
${ }^{12}$ The definition pertains to the franchise agreement, unlike the definition in the European franchise ethics code pertaining to franchise as a marketing system: "The franchise agreement is an agreement in which the owner of a brand or a brand name grants the right of its operation to a physical person or legal entity called franchisee, in order to market products or to provide services for a fee. » (Section 14 of the Tunisian Law of August 12, 2009).

${ }^{13}$ Chamber of Commerce and Industry of Tunisia
} 
According to the institutional isomorphism phenomenon identified by institutional theory (DiMaggio \& Powell, 1983), franchising in emerging countries can be accepted as a legitimate institutional form and as a normal choice in the organization of an outlet network. Foreign brand names, often French ones in the case of Morocco, Tunisia or Algeria, have managed to establish themselves as franchises in these countries, relying on socially and culturally well-anchored local firms. It can be expected that national firms will soon launch their own distribution networks. The example of Morocco, where 15 percent of all franchise chains are Moroccan, illustrates this trend.

Our survey of the evolution of franchising in the three North African countries has also made it evident that deliberate public policies and the institutional environment for franchising (country risk, existence of modern business structures, laws and institutions specific to franchising) are prerequisites for the successful deployment of foreign franchising, which conditions the development of national franchising. The lessons of the institutional theory, explaining the development of an organizational form by the players' mimetic rationality are verified: franchising is adopted by local firms in emerging countries only if 1) the institutional environment is favourable to the establishment of international franchisors, and if 2) the local players can see that this business format can be successful. In this paper, we developed an analytical framework that captures the institutional environment of franchising, which may be useful for franchisors wishing to export their services.

In the case of the Maghreb, we noted that while franchising could not take off in Algeria because of mistrust by the authorities, it was already well established in Morocco, and should grow rapidly in Tunisia, as the government recently adopted more franchising-friendly policies as it recognized the benefits of franchising for the national economy. Franchising can help in the modernization of the national business structures. Franchising allows a greater structuration and more transparency in trade. Franchising can represent an asset for combatting the informal economy, black markets and even counterfeiting. Franchising also fosters entrepreneurship, thus contributing to the creation of new firms, the development of self-employment, and a spirit of self-reliance and innovation. This has been the Moroccan policymakers view, and now it is also the Tunisian policymakers' as well. Finally, the extract below appears as an exemplary synthesis of the situation in Maghreb, outlining the key role of the institutions surrounding franchising in the development of networks. 


\section{Extract from expert, Jean-Yves Moisseron interview ${ }^{14}$}

The study of the dynamics of franchises is an excellent indicator of institutional configurations that distinguish seemingly similar countries such as Tunisia, Morocco and Algeria. If the weakness of franchised businesses in Algeria seems very logical in an essentially rentier country where most of trade is controlled by the state or tolerated in many informal networks and tolerated, the differences with Morocco and Tunisia are amazing. While Tunisia regularly appears as a better candidate than Morocco in terms of indicators of "good governance", this country remains far below in the development of franchise business. A key explanation is the nature of the institutions that surround the franchise and contribute to its development or not in a given environment. The difficulty lies in our ability to understand and measure this complex and multifaceted reality that institutions represent.

Different social sciences do not have the same definition while indicators are supposed to report both numerous and marked by different normative intentions. Any indicator of institutions tends to "crush" becoming a proxy dense realities listed in the thickness of social logic.

This is where designs or comprehensive surveys can explain the paradox highlighted between Morocco and Tunisia with respect to the development of franchise networks.

Tunisia remains a small country, closely administered with low separation of powers, including judicial and police, which has a tradition of international trade control despite his involvement in a number of free trade agreements. In the last years of the reign of Ben Ali, the economic insecurity of companies has increased significantly including the establishment of a predatory system that forced companies to seek political protection and to share their profits with close power as "briberies" or various fees. Far from being stabilized, this informal system of predation did not offer sufficient stability horizon for potential franchisees. Instead, the franchise, with the importance of brands, mostly French, made especially visible in the public space the vulnerability of companies to political disputes about human rights, between France, Europe with Tunisia. The visibility of the franchise was reinforced by its concentration in the area of Greater Tunis.

The political economy of the franchise in Morocco is different. Franchises are more geographically dispersed. Moroccan policy aims to modernize the urban space as shows trams in Rabat and Casablanca, where franchise as a visible place in the modernization of consumption practices, explicitly encouraged. The presence of a resident European diaspora is another explanatory factor. Moreover, trade and imports were more decentralized and liberalized in Morocco and Tunisia. Morocco has finally committed against corruption for many years, especially during the implementation of the Central Authority for the Prevention against Corruption in 2007, which reduces economic uncertainty for businesses.

Institutional logics that govern the development of franchise are multifaceted and not fully captured by quantitative indicators of governance.

\section{CONCLUSIONS}

The literature on the spread of franchise chains in emerging countries is rich in examples where the facilitating part of the authorities and of the institutional framework in the implementation of networks is observed, in China and in Asia, in general, in Latin America and in most emerging countries, (Isa, 2012; Yu \& Ramanathan, 2012). Our main contribution in this study is to propose an analytical framework of the institutional environment specific to franchising that helps explain the development of franchising in emerging countries, using the three largely similar North African countries of Algeria, Morocco, and Tunisia. As we could readily explain the uneven development of franchising in the three Maghreb countries through the specific institutional environment of each country, our study provides empirical support for institutional theory. It appears that institutional theory complements agency theory and resource scarcity theory in explaining the development of franchising in emerging markets: while agency theory and resource scarcity theory explain the motivation of firms to expand internationally

\footnotetext{
${ }^{14}$ Jean-Yves Moisseron is an Economist and researcher at Institut de Recherche sur le Développement http://en.ird.fr/ in Paris. He is a specialist of geopolitics in Maghreb and the Arabic world. The interview was conducted in Paris, on June 26, 2013.
} 
through franchising, institutional theory helps explain the success or failure of these firms in the emerging markets they expanded to. This study underscores the fact that franchise firms need to pay very close attention to the institutional environment of the countries they are targeting for entry as it is a determining factor in their success or failure in these countries. This study also reinforces the common sense belief that policymakers in emerging countries that wish to develop a vigorous national franchising sector need to develop policies that foster a healthy economic and political environment, a fair and transparent legal and regulatory environment, and a performing business infrastructure. In this respect, this study has contributed to the identification of best practices in franchising development in emerging countries.

As this is an exploratory study, our findings should be considered preliminary and need to be extended. First, our contribution requires additional and more in-depth observation of franchise networks development in the Maghreb countries, all of which are experiencing important changes, particularly Tunisia, the cradle of the "Arab Spring" that began in December 2010. These changes have a marked impact on the institutional environment of these countries, and therefore on the future of franchising there. It would be valuable to update this study after the political and social situations in the three countries, particularly Tunisia, stabilize. Though this study focused on the three North African countries composing the Maghreb, it could be extended to other important African countries such as Egypt and South Africa. It would be worthwhile to contrast the evolution of franchising in these other African countries to those in the Maghreb ${ }^{15}$. Another relevant research perspective is to analyze the institutional proximity between institutional characteristics of the "mother" country of the network and the target country. The preparation of this paper preceded the events of December 2010 and the Jasmine evolution in Tunisia, as it was started at the beginning of 2010, following the doctorate research of one of the authors on trade structures in Algeria. A question arises in view of what occurred in 2011 in the Arab countries: what are the consequences of the revolutions on trade structures in general and on foreign franchising in particular? Riots were observed during the Jasmine revolution in Tunisia, against foreign brand names (for example Monoprix, Géant and Carrefour). Some of the pillaging proceeded from hunger riots, but other more political forms of looting were directed at groups supposedly close to the former regime, including national and international retailing chains (LSA No. 2169). However, although the revolutions slowed down trade for a few months, foreign brand names, particularly the French firms managing brand names as franchises in Tunisia quickly announced significant investment and development programmes in the country, as there was potential for growth and the authorities declared themselves in favour of franchises. It is probable that the desire to gain economic and social progress will speed up franchising as an efficient and legitimate marketing system in the North African countries provided that the institutional environment favours franchising.

\section{ACKNOWLEDGEMENTS}

The authors express their deepest gratitude to Jean-Yves Moisseron, Economist and researcher at Institut de Recherche sur le Développement in Paris, France, who highly contributed to improve our paper, through stimulating exchanges

\section{AUTHOR INFORMATION}

Hachemi Aliouche is Director of the Rosenberg International Franchise Center, University of New Hampshire, USA. He holds a PhD and a M.A. in Economics from the Whittemore School of Business and Economics, as well as a B.S. in Electrical Engineering (University of New Hampshire), and a Mini-MBA in Finance (Wharton School of Business). E-mail: hachemi.aliouche@unh.edu

Dominique Bonet Fernandez is Professor at IPAG Business School in Paris, France and affiliated to the Center of Research on Transport and Logistics (CRET-LOG) at Aix-Marseille Université. She holds an MBA degree from Ecole des Hautes Etudes Commerciales in Montréal, Canada and a PhD in Management Science from Aix-Marseille Université. E-mail: dominique.bonet-fernandez@ipag.fr

\footnotetext{
${ }^{15}$ For a study of the franchising in Egypt, see Grunhagen et al (2010).
} 
Odile Chanut is Professor at Aix-Marseille Université, France and Director of Research at the Center of Research on Transport and Logistics (CRET-LOG). She is graduated in Economics and Finance from Sciences Po Paris, in Law from Paris I Pantheon Sorbonne and holds a PhD in Management Science from Université de Savoie. She published a book on franchise networks («Les réseaux de franchise », Paris, La Découverte, 2010, co-written by J. Boulay). E-mail: odile.chanut@univ-amu.fr

Nadjoua Gharbi is Assistant professor at the Université de Constantine, Algeria. She holds a $\mathrm{PhD}$ in Management Science from Université Badji Mokhtar, Annaba, Algéria. E-mail: nad252001@ yahoo.fr

\section{REFERENCES}

Abbad, H., Paché, G., Bonet Fernandez D., (2013), "Building a long-term relationship between manufacturers and large retailers: limitations of a commitment-related approach", Journal of Applied Business Research. vol. $29, \mathrm{n}^{\circ} 5,1367-1380$.

Adimi, K. (2010), "Implanter sa franchise au Maghreb : trois différentes cultures des affaires dossier,26/01/2010,consultable.sur http:///www.lesechosdelafranchise.com/maghreb/implanter-safranchise-au-maghreb-trois-differentes-cultures-des-affaires-9347.php

Aliouche, E.H., Schlentrich, U.A. and Frazer, L., (2012), "Internationalization Modelling: A Comparative Analysis of American and Australian Franchise Firms", Journal of Marketing Channels, 19, 1, 77-97.

Aliouche, E.H. and Schlentrich, U.A., (2011), "Towards a Strategic Model of Global Franchise Expansion”, Journal of Retailing, 87, 3, 345-365.

Alon, I. and Mckee D.L., (1999), "The internationalization of professional business service”, Journal of Consumer Marketing, 16, 1, 74-85.

Antonowicz A. (2011), "The dissemination of franchising all over the world: an attempt to assess the scale of the phenomenon", Problems of Management in the 21st Century, 2, 8-18.

Barthelemy, J., (2011), "Agency and institutional influences on franchising decisions", Journal of Business Venturing, 26, 1, 93-103.

Baudry, B., (1999), "L'apport de la théorie des organisations à la conception néo-institutionnelle de la firme : une relecture des travaux de O.E. Williamson", Revue Economique, 50, 1, 45-69.

Benmiloud, H. (2013), “La franchise, un moyen de développer l'entrepreneuriat chez les jeunes”, Liberté, Quotidien National d'Information, 21 juin 2013.

Bercovitz, J., (2001), "The option to expand: the use of multi-unit opportunities to support self-enforcing agreements in franchise relationships", Working Paper, Fuqua School of Business, Duke University

Capo, C. and Chanut O., (2012), "Quand la proximité crée la convenience : une grille de lecture du système de distribution japonais", Les Cahiers Scientifiques du Transport, $\mathrm{n}^{\circ}$ 61, 2012, 91-117.

Chanut, O., Gharbi, N., Bonet Fernandez, D., (2013), "Institutional Environments and the internationalization of franchise chains: the contrasting cases of North African countries", Proceedings of the 27th Annual, International Society of Franchising Conference, Franchise Management School, Beijing Normal University-Zhuhai, People's Republic of China

Boulay, J. and Chanut O., (2010), Les réseaux de franchise, Paris, La Découverte.

Brickley, J. and Dark F., (1987), "The choice of organizational form: the case of franchising", Journal of Financial Economics, 18, 2, 401-420.

Combs J., Michael S. and Castrogiovani G. (2004), "Franchising: A Review and Avenues to Greater Theoretical Diversity", Journal of Management, 30, 6, 907-931.

Combs J., Michael S. and Castrogiovani G. (2009), "Institutional Influences on the Choice of Organizational Form: "The Case of Franchising", Journal of Management, 35, 5, 268-1290

Davis, L. and North, D., (1971), Institutional Change and American Economic Growth. Cambridge, UK: Cambridge University press.

Di Maggio, P. and Powell, W., (1983), "The iron cage revisited: institutional isomorphism and collective rationality in organizational fields", American Sociological Review, 48, 2, 147-160.

Di Maggio, P. and Powell, W., (1991), "Introduction", in W. Powell and P. Di Maggio (eds), The New Institutionalism of Organizational Analysis. Chicago. University of Chicago Press.

Dumoulin, R. and Gauzente, C., (2009), "Les facteurs d'institutionnalisation de la franchise et leurs conséquences sur la performance", Management \& Avenir, 22,155-170. 
Duniach-Smith, K., (2003), La franchise internationale : une contribution à l'étude des modes d'entrée à l'étranger, Thèse de doctorat en Sciences de Gestion, Université de Montpellier 1.

Eroglu, S., (1992), "The internationalization process of franchise systems: a conceptual model”, International Marketing Review, 9, 5, 19-30.

Fédération Française de la Franchise (2011), Toute la franchise : les textes, les chiffres,

les réseaux, Paris, Fédération Française de la Franchise.

Fladmoe-Lindquist, K. and Jacques, L., (1995), "Control modes in international service operations: the propensity to franchise", Management Science, 41, 7, 1238-1249.

Gauzente, C., Dumoulin, D. (2012), "Franchising choice in retail networks: A multi-level institutional framework", International Review of Retail, Distribution and Consumer Research, 22, 4, 385-396.

Gharbi, N., (2008), La franchise comme stratégie de transfert des savoirs faire marketing : étude de cas l'Algérie, Actes du $4^{\text {ème }}$ forum Alliances Stratégiques et Amélioration des Performances des PME / PMI Algériennes, Annaba, Algérie.

Gharbi, N., (2011), L'impact des marchés commerciaux informels sur les politiques marketing des grandes surfaces: étude de cas d'Alger. Thèse de doctorat en Sciences de gestion, Université Badji Mokhtar, Annaba, Algérie

Grunhagen, M., Witte, C. L., and Pryor, S., (2010), "Effects of US-based franchising in the developing world: a Middle-Eastern consumer perspective.” Journal of Consumer Behaviour, 9: 1-17.

Isa, F., Hoe, C., Othman, S.N., Din, M. S., Mohd Harif, M.A.A., Hussin, Z. and Jani, M. Y., (2012), "The Extent of Marketing Capability and Market Orientation in Franchise Business in Malaysia", International Journal of Business and Social Science Vol. 3 No. 10 [Special Issue - May] 325-334.

Jensen, M. and Meckling W., (1976), "Theory of the firm: managerial behaviour, agency cost and ownership structure", Journal of Financial Economics, 3, 4, 305-360.

Kosová, R. and Lafontaine F., (2011), "Understanding franchising: A new look at U.S. franchisor activities", Economies et Sociétés, série Dynamique technologique et organisation, W, 13, 873-892.

Lafontaine, F., (1995), Pricing decisions in franchised chains: a look at the restaurant and fast-food industry, Working Paper, NBER 5247.

Lawrence, P. and Lorsch, J., (1969), Organization and Environment. Homewood, IL : Irwin.

Moisseron, J.-Y., Abis, S., Velud, J. and Teulon, F., (2013), Les effets divergents du printemps arabe sur la coopération euro-méditerranéenne en Tunisie et au Maroc, accepted paper, Maghreb Machrek.

Mseddi, W. and Bouri A., (2010), La franchise en Tunisie : état des lieux, Actes du $6^{\text {ème }}$ Colloque International de Laboratoire Prospective, Stratégie et Développement Durable (PS2D) de la Faculté des Sciences Économiques et de Gestion de Tunis, Hammamet, Tunisie.

North, D., (1990), Institutions, Institutional Change and Economic Performance. Cambridge, MA: Harvard University Press.

Norton, S., (1988), "An empirical look at franchise as an organizational form”, Journal of Business, 61, 2, 197-218.

Oliver, C., (1997), "Sustainable Competitive Advantage: Combining Institutional and Resource-based Views", Strategic Management Journal, 18, 679-713.

Quinn B., Alexander N. (2002), "International retail franchising: a conceptual framework", International Journal of Retail and Distribution Management, 5, 264-276.

Peng, M.W.,(2000), Business Strategies in Transition Economies, Thousand Oaks, CA:Sage

Peng, M.W.,(2002), Cultures, Institutions and Strategic Choices: Toward an Institutional Perspective on Business Strategy, in M. Gannon and K. Newman (eds), The Blackwell Handbook of Cross-Cultural Management, pp 52-66. Cambridge, UK: Blackwell.

Powell, W., (1996), "Commentary on the Nature of Institutional Embeddedness", Advances in Strategic Management, 13, 293-300.

Shane, S. and Foo, M.-D. (1999), "New firm survival: Institutional explanations for new franchisor mortality", Management Science, 45, 142-159.

Stanworth, J., Price S. and Purdy D., (2001), Franchising as a source of technology transfer to developing economies, Proceedings of the $15^{\text {th }}$ Annual Society of Franchising Conference, Las Vegas, Nevada.

Stanworth, J. and Curran J., (1999), "Colas, Burgers, Shakes, and Shirkers; towards a sociological model of franchising in the market economy", Journal of Business Venturing 14, 323-344.

Welsh, D., Alon, I. and Falbe, C., (2006), "An examination of international retail franchising in emerging markets", Journal of Small Business Management, 44, 1, 130-149. 
Weatherspoon, D., Neven, D., Katjiuongua, H., Fotsin, R., Reardon, T. (2004), "Battle of the supermarket supply chains in Sub-Saharan Africa: challenges and opportunities for agrifood suppliers", United Nations conference on trade and development, http://unctad.org/en/Docs/ditccommisc20035_en.pdf

Yang, Z., Su, C. and Farn, K-S., (2012), "Dealing with Institutional Distances in International Marketing Channels: Governance Strategies That Engender Legitimacy and Efficiency", Journal of Marketing, 76.3.

Yu, W. and Ramanathan, R., (2012), "Effects of Business Environment on International Retail Operations: case study evidence from China", International Journal of Retail \& Distribution Management, 40.3, 218-234. 


\section{APPENDIX}

Appendix A: Components Of The Euromoney Country Risk Index

\begin{tabular}{|l|c|}
\hline \multicolumn{1}{|c|}{ Measure } & Weight \\
\hline Political risk & $30 \%$ \\
Economic performance/projections & $30 \%$ \\
Structural assessment & $10 \%$ \\
Debt indicators & $10 \%$ \\
Credit ratings & $10 \%$ \\
Access to bank finance/capital markets & $10 \%$ \\
TOTAL & $100 \%$ \\
\hline
\end{tabular}

Source: Euromoney Country Risk (2011)

Appendix B: Components of the World Bank Doing Business Index

Starting a business Measures (equally weighted)

Dealing with construction permits

Registering property

Getting credit

Protecting investors

Paying taxes

Trading across borders

Enforcing contracts

Closing a business

Source: World Bank, Doing Business (2011) 